\title{
I Wish, I Wonder, and Everything I Like: Living Stories of Piano Teaching and Learning With Young Children
}

Jee Yeon Ryu

\begin{abstract}
The purpose of my inquiry is to learn more about how young children learn to play the piano through examining my own teaching practice. By using autoethnography as a creative nonfictional form of storytelling, I illustrate my learning journey in search for joyful and meaningful ways of exploring music and piano playing with young beginner students. In writing stories about my learning experiences as a piano teacher, I discuss the importance, value, and need for piano teachers' autoethnographies.
\end{abstract}

"In the mornings, I just like to fool around and make up my own songs."

In our piano lessons, my students and I like to create our own music. Sometimes, we find inspirations from imitating the sounds of our favorite animals. We play quietly for the little chicks or butterflies, and loudly for the big elephants or bears. Our fingers jump and bounce across the piano keys like the monkeys or kangaroos, and glide across the piano keys like the hissing sounds of the snakes. For the roaring lions, we play the lowest keys on the piano. For the little animals hiding away into the forest, we try to reach for the highest keys. Depending on the characteristics of the animals, we move our fingers as quickly as possible like the horses freely running across the fields or very slowly like the big freshwater turtles. Sometimes, we mix all the sounds of our favorite animals as if we are in a deep magical jungle.

Aside from our favorite animals, we find inspirations from our favorite storybooks. As I read a story, my students happily create wonderful sound effects on the piano.

On some days, we even draw pictures to inspire musical ideas and "notate" our piano improvisations. On other days, we just like to play and make up our own music without referring to any particular ideas or stories. We simply play and let our musical ideas flow as we freely improvise across the piano keys.

Between our creative piano play, we also like to carry on long conversations about music or anything else that captures our imagination.

"You know what? I have to tell you something," my students like to say.

In this paper, I use autoethnography (Adams, Jones, \& Ellis, 2014; Bartleet \& Ellis, 2009; Bochner \& Ellis, 2016; Chang, 2008; Ellis, 2004, 2009; Ellis \& Bochner, 2000; Jones, Adams, \& Ellis, 2013; Reed-Danahay, 1997; Richardson, 2000)—as a creative nonfictional form of storytelling-to examine how my students and I have been exploring music and piano playing with one another. By sharing my 
piano teaching and learning stories, I reflect on my ideas, questions, and challenges that I encountered in our lessons, and discuss the importance, value, and need for piano teachers' autoethnographies.

Traditionally speaking, autoethnography is a form of nonfiction writing [i.e., "graphy"] about the self [i.e., "auto"] and one's relationship to culture [i.e., "ethno"]. However, in the Greek language, "auto" means much more than self-depending on the conversational context it can also mean him, her, this, that, those, they, and other (Gouzouasis \& Ryu, 2015, p. 403). For me, learning about those multiple, contextualized meanings of the prefix "auto" opened up a whole new way of thinking about various forms of storying the self (see Leggo, 1995; 1997; 2003).

In other words, while I use a first-person voice to tell stories about my learning experiences as a piano teacher (i.e., "auto"), the conversations and interactions that I have with my students (i.e., "ethno"), and the ways in which they inform my teaching call for a relational approach to thinking, researching, and writing about piano pedagogy (i.e., "graphy"). As I draw attention to particular emotions, objects, and experiences, my engagement and relationships with young children are deeply influenced by my being a part of a particular culture (Gouzouasis \& Ryu, 2015, p. 403). In that sense, as the multiple, contextualized meanings of "auto" are fused with "ethno" and "graphy," the notion of "self" extends beyond the "personal" as it forms holistic, embodied, and relational perspectives about the ways in which the person (i.e., the piano teacher and student) both enacts and writes the story. As an autoethnographic storyteller, I am an active member and partner in the creation, and re-creation of a story (p. 403).

With those ideas in mind, I herein share three stories about my everydayness as a piano teacher. ${ }^{1}$ They are my living stories that have no predetermined conclusions or definitive learning outcomes. Rather, I explore, evoke, and share my learning journey, which is still in the process of becoming. They are my metaphorical fragments of my life stories-of teaching, writing, and researchingconcerning what it means to be with young children when exploring music and piano playing together.

As such, I write about my personal, interpersonal, and intrapersonal experiences of piano teaching and learning with young children by using open-ended, interpretive storytelling. I focus my stories on actions, dialogues, and emotions. To describe the events and situations in our lessons that moved and puzzled me, I write in a style of "small stories" (Nutbrown, 2011) and "tales" (van Maanen, 1988/2011) that draw attention to particular teaching and learning moments and experiences. To recall and describe meaningful moments, memories, and conversations that deeply resonated with me, I write my stories in the present tense to draw the readers immediately into the experiences (Bochner \& Ellis, 2016, p. 109).

Writing and sharing stories enable me to connect the "self" with "others" to make meaningful connections between the personal and people (Doty, 2010, p. 1048). By inviting my readers to "re-live" (Richardson, 2000, p. 11) the experiences through emerging themselves in the dialogue and reading the stories as if they are the teacher in the story, I seek to communicate the "truth-likeness" and "verisimilitude" (Eisner, 1997, p. 264).

From that dialogical perspective, the stories that follow may be considered as more than merely a "personal" story of one teacher's journey in learning. As I share my experiences of working with the 
I Wish, I Wonder, and Everything I Like: Living Stories of Piano Teaching and Learning With Young Children

beginner piano students, and how they changed my ideas and understandings about what really matters in piano lessons for young children, I wish to encourage and inspire other music/piano teachers to become more mindful of their life stories (see Leggo, 1995). By using my living stories of exploring music and piano playing with young children to reflect on their own perspectives, understandings, and experiences (Bochner \& Ellis, 2016, p. 219), I hope that my readers will discover new insights and connections in relation to what they find meaningful in their teaching and learning practices.

\section{Story I: Old McDinosaurous}

I met Jimmy ${ }^{2}$ about six months ago. He is six years old, and he loves to run. Every time I greet him in the waiting room, he is always ready to race me down the hall to our piano studio.

But, as much as he loves to run, I think he enjoys the winning prize even more because if he wins the race, he can lock me out of the room.

Jimmy is a fast runner. He always wins the race.

As soon as he enters the studio, he sits against the door so that I won't be able to open it.

As I start knocking, "Knock, knock, knock ... Is Jimmy there?"

I can hear him giggling as he pretends to ignore me.

So, I try it again.

"Knock, knock, knock... Where is Jimmy?"

He continues to pretend not to hear me.

More giggles follow.

He loves that.

He loves to pretend not to hear me. He loves to lock me out of the studio.

$\mathrm{He}$ is little but he is determined. There is no way that I can open the door without Jimmy letting me in. I need to be invited. I need his permission.

I know what Jimmy is really waiting for. The only time he ever opens the door for me is if I promise him a story.

He loves to read. He loves stories.

Every week, Jimmy races me to our piano studio and hides behind the door with a storybook in his hands. Every week, I'm always locked out of our studio until I make a promise to him that we will read a story together. Jimmy is always ready to wait as long as he needed to until I say the magic words.

"Knock, knock, knock... Is Jimmy there? It's time for our story. Where is Jimmy?"

As soon as he hears my promise, he happily climbs onto the piano bench ready to begin our piano lesson.

With my promise, he is always ready to let me in.

Jimmy's favorite story is the Berenstain Bears and the Big Road Race. ${ }^{3}$ Even though we have read the same book many times, he always has new questions about the racing cars in the story. He always wants to know more about the four big cars, Orange, Yellow, Green, and Blue. He especially cheers for the Little Red.

When the race begins in the story, Jimmy happily creates the sound effects on the piano.

As I read, "R-r-r!" said Orange, long and low," Jimmy plays the long R-r-rolling sounds on the lower keys of the piano.

When I say, "Vroom!" said Yellow, ready to go," he plays the thunderous chords and freezes in ready position as he waits for the next line in the story. 
As I continue, "Grrr!" said Green, big and mean," Jimmy cringes his face as he plays the fast tremolos.

But, when it is time for the Blue car, Jimmy likes to beat me to the next line in the story.

As he hurriedly places his two little fingers on the two black keys, Jimmy is ready to read about his favorite racing car himself.

As he whispers, "Putt-putt-putt, said Little Red," Jimmy begins to play the two black keys quietly. Just like the sounds of the Little Red trolling along the race track, he decides to play the two black keys three times.

And, as we continue to read, Jimmy playfully provides the music accompaniment for our story. When the cars went over, under, around, and through, Jimmy's hands crosses over, under, and around the piano keys.

As the cars went up and down, down and around, Jimmy jumps up and down from the low to the high notes.

When the cars went through the town, he improvises the bustling noises of people walking around the streets.

And, whenever the cars went through the country scene, Jimmy is always ready to play his own favorite versions of the Old McDonald song, the Old McDinosaurous.

\section{Wish: Reflecting on "Old McDinosaurous"}

The Old McDonald is a very special song for Jimmy. This is not only his favorite, but it is the only song that he ever wants to play on the piano.

Jimmy is neither interested in learning to play the "new" songs nor learning to read from the music books. He just wants to read the storybooks and play his variations of the Old McDinosaurous.

During the weeks when Jimmy started to race me down the hall to lock me out of our studio, I was desperately trying to find ways of connecting with him. I kept asking myself: How can I help Jimmy to gain more interest in piano playing? What can I do to help spark his curiosity about music? How might I be able to encourage more meaningful piano playing experiences?

For us, one of the ways in which we were able to make more meaningful connection to piano playing was with the storybooks. When I related our piano playing to the stories that we were reading together, Jimmy became more interested in learning about the new melodies. He became more curious about piano playing.

For those reasons, storybooks became an important part of our lessons. The stories opened new possibilities for us. Reading stories in our lessons enabled us to find new connections with our piano playing.

For Jimmy, story reading offered more meaningful ways of learning to play the piano.

Every time we read The Berenstain Bears and the Big Road Race, he happily played the Old McDonald, and gradually, he also started improvising his own variations of the melody. In addition to the farm animals in the Old McDonald, we added our own animal sounds to our music. Jimmy's new Old McDinosaurous is named after his favorite animal, the dinosaur.

But, I knew that we couldn't always just read his favorite storybooks and make up our own songs in our lessons. He is expected to learn the "real" piano music. I am expected to "teach" him how to play the "real" songs.

And, it was during those times when Jimmy and I were discovering new ways of connecting storybooks with our piano playing that I found out about his mother's decision to discontinue our lessons. Because we were not learning to "read" traditional music notation, and spending most of our time making up songs and reading storybooks, Jimmy's mother felt that he was not ready for the piano lessons.

She said, "We'll come back in another year or two when Jimmy is able to better focus and concentrate. We'll wait until he is little older." 
When I think of Jimmy, I think of all the stories and creative piano playing that we shared with one another. I think of all those times when he ran down the hall to lock me out of the studio. It still brings smiles to my face when I think of all those days when I hopelessly tried to convince Jimmy to open the door for me.

It is true that Jimmy learned only the one "real" song during the year. But, when I consider how much he loved the stories and how they inspired his creativity and curiosity for piano playing, I now wish that I read him more stories instead of trying to introduce "new" songs for him. Rather than trying to "teach" him new melodies that I wanted him to learn, and to "read" notes from the music books, I wish I could have given him more support for his need for the stories.

After all this time, I can still hear him shouting with great excitement, "Again! Again! Let's read the story again!"

From Jimmy, I learned to trust my students' own ways of connecting with piano playing. He reminded me to have faith, courage, and patience in discovering the unknown, endless ways of piano teaching and learning. He helped me to become more attentive to my students' interests, and approaches in exploring music and piano playing.

In writing Jimmy's story, I started thinking about the pedagogical possibilities in the emergent, improvisational moments in my young learners' processes of making music and piano playing.

Reflecting on his story helped me to realize that it wasn't Jimmy who wasn't always ready for the piano lessons. It was me who wasn't always in presence with Jimmy. When he was locking me out of our studio, it wasn't him who wasn't ready to open the door. It was me who wasn't ready to recognize his needs, interests, and joy for learning to play the piano through storybooks.

\section{Story II: Eyeball Song}

Every week, I know Karla is waiting for me because I can see her golden curly hair swaying back and forth in front of the little window on my studio door.

When she arrives for her piano lesson, she always checks to see if I'm in the room. Because she is not yet quite tall enough to look through the window on my studio door, Karla presses her ear against the door to see if she can hear me playing the piano. Every week, her beautiful golden curly hair flows across the window on my studio door.

When I open the door, I see Karla smiling with her music bag on the floor. She has many music books - all handed down from her older sisters and cousins from long ago. They are wonderfully messy -all covered with colorful handwritings, notes, and pictures by her sisters, cousins, and their teachers.

But, Karla doesn't like the music books. Whenever I invite her to play a song from the books, she immediately throws them on the floor.

"I want to play my song," she shouts with a big smile.

Even though Karla doesn't like to play the songs from the music books, she loves to play her own music. Her favorite is a very special piece called the Eyeball song.

And so, every week, Karla moves up and down the keys as fast as she can with using only the two index fingers. She likes to play from the lowest to the highest notes on the piano and loves to move up and down the keys until she runs out of energy.

Aside from playing the notes as fast as possible, she also likes to play them all forte too.

But, most importantly, she likes to play the piano in the dark.

"It's time for my Eyeball song," she sings as she walks around the room while turning off all the lights.

"Darker! Darker!" she reminds me, "The eyeball is falling out, and it's tumbling down! It can't see!" 
Every week, I always look for new ways of covering up our studio door window to keep all the bright lights away.

Whenever Karla plays her Eyeball song, we always need to be in complete darkness just like her eyeball tumbling down the piano keys.

\section{Wonder: Reflecting on "Eyeball Song"}

In writing Karla's story, I am reminded of many other similar experiences that I had with young children in exploring music and piano playing. Like Karla, all of my students have their own unique, individual ways and ideas about how they want to "play" the piano.

Sometimes, we just play the piano with one finger. Other times, we like to smash into the keys with both of our fists, palms, and elbows.

From time to time, we experiment with flipping our hands upside down to play the piano backwards. There are days when we play the piano with our foreheads and noses too.

At one time, we even thought of using the right arm underneath the left leg. The young ones always ask about playing the piano with their toes.

For us, playing the piano in a choppy, karate style is a lot of fun. Just like Karla, many children also love to play the piano in the dark - but with their eyes closed.

There are many "new" ways of playing the piano. For young beginner piano students, learning to play only the simple, traditional songs with one hand at a time is not always fun, playful, and inviting. Rather, they love to think of all the "new" and "different" ways that they can play the piano. There are endless possibilities.

For us, there are no "right" and "wrong" ways of piano playing. We always think of more "new" ways of playing the piano.

During the months when Karla was only playing the "eyeball" song in the dark, I wondered if I was really helping her to "learn" to play the piano. I knew that she loved making up her own songs. She never wanted to stop. I also knew that she was having a lot of fun trying to play the piano in the dark. However, while listening to her "eyeball" week after week, I felt conflicted about the appropriateness of our lessons. I found myself struggling in what Dewey (1938) calls the "Either-Or" (p. 17) worlds of piano teaching (see Ryu, 2017b).

In one of the worlds, I felt that I needed to continue playing the "eyeball" song in the dark as long as Karla wished to do so. I knew that Karla loved playing in the dark. No matter how long it was going to take, a part of me wanted to wait until she was ready to move forward.

In my other world of teaching, I was concerned about just playing the "eyeball" song in our lessons, and I couldn't help thinking that I needed to change Karla's mind about playing the piano in the dark. I kept telling myself that there must be something more that I could do to encourage Karla to move forward from just playing the "eyeball" song in our lessons.

Even though Karla is now happily learning to play the melodies in her music books, I still wonder about our early years of playing the piano in the dark. While she has long forgotten her one and the only Eyeball song, I still think about the pedagogical meanings, influences, and impressions that our lessons may have had in her first year of exploring music and piano playing.

After all these years, I continue to ask myself:

What is piano playing?

What is teaching? 


\section{Story III: Rice Crackers}

Jack and I are learning to play the Hot Cross Buns by naming all of his favorite snacks.

"What is hot cross bun?" he asks.

"Mmm, hot cross bun is like a warm yummy mini muffin with the shape of a cross drizzled on top," I explain.

"Oh, I don't like mini muffins," he replies without any hesitation.

In hopes of regaining his interest, I ask again, "What is your favorite snack Jack?"

Without a second thought, he replies with excitement, "Rice crackers!"

In that moment, I change the words, and sing the song again, "Rice crackers, rice crackers, yummy, yummy, rice crackers."

"I also like strawberry," he smiles.

"Spaghetti too," he goes on. He also lets me know that it is very important to have lots of good meatballs in his spaghetti.

"How are we going to sing the word 'meatballs' for our three black keys?" I ask.

After a long pause, he cries out with great confidence, "Me-eat-balls!"

He then quickly reaches over for my crayons and starts to pick out the different colors for each of his favorite snacks. I help him place all of the pink and red crayons for his strawberry. We then find the yellow colors for the spaghetti and brown colors for the meatballs.

"I like bananas," Jack shouts as he grabs the yellow crayons and places them on the three black keys.

As we place the crayons on the new set of three black keys, we hum along and play the Hot Cross Buns melody with different kinds of Jack's favorite snacks.

"Rice crackers ... Strawberries ... Spaghetti ... Me-eat-balls ... Bananas ..."

We continue to play our new Hot Cross Buns over and over again as Jack happily sings the names of his favorite snacks.

Then, just before finishing one of his new favorite snack songs, Jack suddenly stops, slowly slips down the piano bench on his own and whispers to me, "Now it's time to go see Mom."

Just like that, our piano lesson was over.

\section{Everything I Like: Reflecting on "Rice Crackers"}

Jack inspired me to transform the Hot Cross Buns into a much more meaningful music for my students. Before meeting with him, I always used to "teach" the songs with the original words. I neither thought to change them nor considered other possibilities by asking for everyone's favorite snacks.

In my early years of teaching, I was used to "teaching" the music as I knew and learned from my past experiences. Although I always asked my students if they recognized and liked the music that I played for them, I never thought to change the words and create new versions of the melodies according to their interests and experiences.

But, now, we have many different versions of Hot Cross Buns according to the various types of snacks that my students like.

Sometimes, we sing, "Cheese pizza, cheese pizza, yummy, yummy, cheese pizza."

Other times, it becomes, "Chocolate, chocolate, yummy, yummy, chocolate." There are days when we sing lollipops, apple pie, and marshmallows. We also think of our favorite vegetables like broccoli, carrot sticks, and potatoes.

When the names of our favorite snacks don't match the three-note rhythm, we create new melodies to match our piano playing. Without using any technical and theoretical terms, we begin to explore the different types of rhythm by figuring out the number of syllables in the words. We like to think of new ways of playing our own versions of the Hot Cross Buns. In one week, it is our Candy 
Cane song. In another week, it changes to the Macaroni song. If we don't want to use a particular name of the snacks that we like, there are days when we simply refer to it as our Favorite Snack song.

In writing Jack's story, I gained renewed sense of wonder, respect, and appreciation for my students' "wonderful ideas" (Duckworth, 2001, p. 181; Duckworth, 2006) about their own ways of learning to play the piano. Thinking about our piano lessons encouraged me to be more mindful of each child's freely moving stories, ideas, and questions. It inspired me to continue researching for more meaningful ways of imagining, understanding, and making connections with music and piano playing.

In storying how my students and I have been exploring music and piano playing, I started examining who I am and who I can be as a piano teacher. In writing my piano teaching and learning stories, I found a pedagogic space, place, and time for me to reflect on my questions, ideas, and hopes for creating more positive piano learning experiences.

My students encourage me to continue searching for more meaningful ways of nurturing children's joy, wonder, and curiosity for music and piano playing. Each child responds to the music and piano playing differently. I can never assume how they will learn to play the piano.

As a result, my lessons are no longer only about the music and piano playing. We move beyond the "topics" and "lessons" that I may have in mind for my students. My piano teaching approaches remain flexible, and our lessons constantly change and evolve to welcome each child's interests, ideas, and questions. I also give my students my full, undivided attention to all the things that they need to say, feel, and think about music and piano playing. No matter what I may have "prepared" and "planned" for the day, I give precedence to what children wish to share with me at any given moment.

For those reasons, it is critical that our music and piano playing relate and connect to what matters in young children's everyday experiences. All of my students' creative, imaginative ways of exploring music and piano playing, and everything else that they wish, wonder, and like in their lives, are our constant inspirations and foundation for creating more pedagogically meaningful, playful, and joyful ways of learning to play the piano.

And so, writing stories about my teaching practice guides me to develop a deeper awareness for all the possibilities in children's own unique, individual ways of exploring music and piano playing. It inspires me to learn alongside my students and to embrace teaching and learning as a reciprocal, emergent process (Custodero, 2005, p. 47).

Through stories, I am learning to be attentive, to question, to ask, and to listen in new ways. Reflecting on my teaching and learning experiences through stories reminds me that our lessons need to include much more than simply learning to play the notes, reading music notation, and developing strong piano-playing techniques.

Playing the piano in the dark, reading and sharing stories, freely improvising our own sounds and music, as well as making up new words and melodies to the songs are all natural parts of the piano learning process. What may seem "irrelevant" and "distractive" in our lessons could incite new ideas, directions, and possibilities for teaching and learning. Listening to my students and taking time to follow their moving interests, ideas, and stories is as important as listening to them play the piano. 


\section{Finale: Value, Importance, and Need for Piano Teachers' Stories}

A piano studio is a place with many stories. There are a great number of questions about piano teaching and learning that require in-depth explorations and discussions. That is why I believe that we need more music teaching and learning stories from piano teachers, and propose that piano teachers' autoethnographies - as forms of storytelling and story sharing - can be one of the ways in which we can bring more insights, understandings, and new ways of deeply thinking about piano pedagogy and piano teacher educational research.

For me, writing my life stories of piano teaching creates openness, curiosities, and possibilities to all the things that my students wish to share with me. The creative process of writing about my life as a piano teacher enables me to live meaningful moments, and to think of more meaningful ways of inviting my students to participate in their own musical learning. It moves me to "dialogue about what is it to be human, to grow, to be" (Greene, 1977, p. 123).

In writing my stories, I commit to the continuous process of piano teaching and learning. Engaging in an autoethnographic inquiry through storytelling teaches me to approach my piano lessons with more "attentiveness, care, and openness to possibility" (Custodero, 2005, p. 51) that includes all aspects of being in pedagogical presence with my students (Hill, 2006; Rodgers \& Raider-Roth, 2006).

Stories about my everyday practices of teaching, researching, and writing draw my attention to the beauties in our everyday moments that I share with my students. It helps me to find more space, time, and place for me to explore, reflect, and practice more artful ways of piano teaching. Writing about my everydayness as a piano teacher encourages me to cultivate awareness of who I am as a piano teacher, and who I have yet to be (Greene, 1984, p. 123). It challenges me to continue asking more questions about what it means to be a piano teacher. It brings me closer to the "presence of the beingness of teaching" (Aoki, 1992/2004, p. 191).

Writing about my piano teaching and learning is an ongoing pedagogical process of discovery. For me, writing stories is pedagogical because engaging in the process of writing the self and the other teaches me about my students, as well as about myself as a piano teacher. It invites me to draw my attention to the shared moments with my students. It calls upon me to be mindful of my piano teaching and learning. It encourages me to question, reflect upon, and seek for more artful, educative (Dewey, 1938) ways of thinking about music and piano playing.

Sharing piano teachers' stories can inspire us to question, evoke, and bring insights to new, creative ways of teaching and learning piano. When I reflect upon my experiences with my students through stories, it provokes me to (re)examine the nature of music and piano learning process for a young child. It engages me in a reflective-reflexive discovery that leads me to think about what it means to play the piano, what it means to learn music as a young child, and how young children acquire piano playing skills. Writing stories opens new ways of (re)discovering possibilities to those questions. 
Through stories, we can evoke nuanced understandings of the complex relationships and teaching/learning processes that occur in our piano lessons. By reflecting on who we are as teachers, our relationships to our students and their parents, we can create pedagogic communities of reflective, reflexive, piano teacher-researchers.

In writing and sharing stories about our everydayness with our students, we can join the ongoing conversations about what it means to teach and learn. We can begin a new journey toward practicing more meaningfully pedagogical ways of exploring music and piano playing with our students. By focusing on children's ideas, curiosities, questions, and wonder about music and life, we can teach with newness and beauty, a quality of awareness for our students' creative, imaginative ways of learning to play the piano. As we celebrate all the things that we wish, wonder, and like, we can embrace music and piano playing as an ever-present living practice, a joyful part of our shared teaching and learning journeys.

\section{Notes}

1. The three stories presented in this paper belong to a collection of stories included in the author's doctoral dissertation (see Ryu, 2017a).

2. All the student names are pseudonyms.

3. All the italics in "Old McDinosaurous" are direct quotes from the Berenstain and Berenstain's (1987) storybook.

\section{References}

Adams, T., Holman Jones, S., \& Ellis, C. (2014). Autoethnography: Understanding qualitative research series. Oxford: Oxford University Press.

Aoki, T. T. (1992/2004). Sonare and videre: A story, three echoes and a lingering note. In W. Pinar \& R. Irwin (Eds.), Curriculum in a new key: The collected works of Ted T. Aoki (pp. 367-376). Mahwah, NJ: Lawrence Erlbaum Associates.

Bartleet, B. L., \& Ellis, C. (2009). Music autoethnographies: Making autoethnography sing/making music personal. Brisbane: Australian Academic Press.

Berenstain, S., \& Berenstain, J. (1987). The Berenstain bears and the big road race. New York, NY: Random House, Inc.

Bochner, A., \& Ellis, C. (2016). Evocative autoethnography: Writing lives and telling stories. New York, NY: Routledge.

Chang, H. (2008). Autoethnography as method. Walnut Creek, CA: Left Coast Press.

Custodero, L. A. (2005). "Being with": The resonant legacy of childhood's creative aesthetic. Journal of Aesthetic Education, 39(2), 36-57. 
I Wish, I Wonder, and Everything I Like: Living Stories of Piano Teaching and Learning With Young Children

Dewey, J. (1938). Experience and education. New York, NY: Kappa Delta Pi.

Doty, R. L. (2010). Autoethnography - making human connections. Review of International Studies, 36(4), 1047-1050.

Duckworth, E. (Ed.). (2001). "Tell me more": Listening to learners explain. New York, NY: Teachers College Press.

Duckworth, E. (2006). "The having of wonderful ideas" and other essays on teaching and learning. New York, NY: Teachers College Press.

Eisner, E. W. (1997). The new frontier in qualitative research methodology. Qualitative Inquiry, 3(3), 259-273.

Ellis, C. (2004). The ethnographic, I: A methodological novel about autoethnography. Walnut Creek, CA: AltaMira Press.

Ellis, C. (2009). Autoethnography as method. Biography: An Interdisciplinary Quarterly, 32(2), 360-363.

Ellis, C., \& Bochner, A. P. (2000). Autoethnography, personal narrative, reflexivity: Researcher as subject. In N. K. Denzin \& Y. S. Lincoln (Eds.), The handbook of qualitative research (pp. 733-768). Thousand Oaks, CA: Sage.

Gouzouasis, P., \& Ryu, J. (2015). A pedagogical tale from the piano studio: Autoethnography in early childhood music education research. Music Education Research, 17(4), 397-420.

Greene, M. (1977). Toward wide-awakeness: An argument for the arts and humanities in education. The Humanities and the Curriculum, 79(1), 119-125.

Greene, M. (1984). The art of being present: Educating for aesthetic encounters. Journal of Education, 166(2), 123-135.

Hill, A. (2006). Making sense of methods in the classroom: A pedagogical presence. Lanham, MD: Rowman \& Littlefield Education.

Jones, S. H., Adams, T. E., \& Ellis, C. (Eds.). (2013). Handbook of autoethnography. Walnut Creek, CA: Left Coast Press, Inc.

Leggo, C. (1995). Storing the word/storying world. English Quarterly, 28(1), 5-11.

Leggo, C. (1997). The story always ends with etc.: Autobiography and poetry. English Quarterly, 29(3-4), 67-86.

Leggo, C. (2003). Backyard quest(ion)s written in stone and water: Alchemic possibilities in the space of the heart. In E. Hasebe-Ludt \& W. Hurren (Eds.), Curriculum intertext: Place/language/pedagogy (pp. 131-148). New York, NY: Peter Lang.

Nutbrown, C. (2011). A box of childhood: Small stories at the roots of a career. International Journal of Early Years, 19(3-4), 1-16.

Reed-Danahay, D. (1997). Auto/ethnography: Rewriting the self and the social. Oxford: Berg.

Richardson, L. (2000). Writing: A method of inquiry. In N. K. Denzin \& Y. S. Lincoln (Eds.), The handbook of qualitative research (pp. 923-949). Thousand Oaks, CA: Sage. 
Rodgers, C. R., \& Raider-Roth, M. B. (2006). Presence in teaching. Teachers and Teaching: Theory and Practice, 12(3), 265-287.

Ryu, J. (2017a). Exploring music and piano playing with young children: A piano teacher's pedagogical stories (Doctoral dissertation). University of British Columbia. Retrieved from https://open.library.ubc.ca/cIRcle/collections/24/items/1.0362235

Ryu, J. (2017b). Deweyan fragments: Erasure poetry, music, and a story. In P. Sameshima, K. James, C. Leggo, \& A. Fidyk (Eds.), Poetic inquiry III: Enchantment of place (pp. 297-304). Wilmington, DE: Vernon Press.

van Maanen, J. (1988/2011). Tales of the field: On writing ethnography. Chicago, IL: The University of Chicago Press

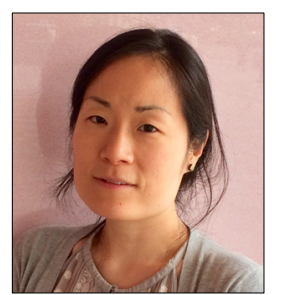

Jee Yeon Ryu completed her PhD in Curriculum and Pedagogy Studies at The University of British Columbia, specializing in music education. As a piano teacher-researcher, she incorporates a variety of artistic genres into her teaching and researching practices, including erasure poetry, piano performance, video, and creative writing. Her artistic/scholarly works have been published in Music Education Research, International Journal of Education Through Art, Poetic Inquiry: Enchantment of Place, and Handbook of Arts-Based Research. 